\title{
PETROLOGY OF A COMPOSITE DIKE WITH BIOTITE GRANITE PORPHYRY AND HORNBLENDE QUARTZ DIORITE PORPHYRY AT SHIROTORI, KAGAWA, JAPAN
}

\author{
OSAMU UJIKE \\ Shikoku Offlce, Geological Survey of Japan, 10-6, Bancho-1, Takamatsu 760
}

\begin{abstract}
A Late Cretaceous composite dike at Kaura-goshi, Shirotori has an inner zone of biotite granite porphyry and outer zones of hornblende quartz diorite porphyry. Considerably altered fragments of the quartz diorite porphyry are distributed in the inner zone and seem to have been incorporated while plastic. The granite porphyry of the composite dike is higher in $\mathrm{mg}\left[=\mathrm{Mg} /\left(\mathrm{Mg}+\mathrm{Fe}^{2+}+\mathrm{Fe}^{3+}+\mathrm{Mn}\right)\right]$ ratio and lower in normative $\mathrm{Q} /(\mathrm{Q}+\mathrm{Or}+$ $\mathrm{Ab}$ ) ratio than similar but simple dike rocks in the area. The salic magma of the composite dike might have been slightly contaminated by the associated quartz diorite porphyry magma at, or earlier than, the stage of magma chamber. It cannot exclude the possibility that salic magmas of different modes of intrusion have different origins.
\end{abstract}

\section{INTRODUGTION}

Contemporaneous igneous rocks of great compositional contrast are widely distributed in nature (Walker and Skelhorn, 1966; Yoder, 1973; Popov, 1976). Their genesis is one of the important subjects of petrological research. Among numerous Late Cretaceous dikes in northeastern Shikoku, is a composite dike with an inner biotite granite porphyry and outer hornblende quartz diorite porphyry. The dike has been briefly described as being composed of granophyre and spessartite by some investigators (e.g. Kawano and Kishida, 1940; Ohara, 1976). The present paper describes the petrography, petrochemistry and mineralogy of the dike, and discusses its petrogenesis from the viewpoint of contemporaneous intrusion of magmas with contrasting composition.

\section{Field Characteristics}

Field characteristics will be described briefly here, and the interested student is referred to Fig. 3 of Kawano and Kishida (1940) for a photograph, and Fig. 1 of Ohara (1976) for a sketch of the whole exposure of the composite dike. In most cases of contact or intersection of the other dikes nearby, the later dike with a salic composition has chilled against the earlier one with a relatively mafic composition (Ujike, 1978). In other words, the dikes with different compositions have intruded by intervals usually and the occurrence of composite dike is scarce among the dike swarm in the area. Details of geology and chemistry of the dike swarm are given in articles (Kawano and Kishida, 1940; Sato, 1936; Ujike, 1978).

The composite dike, about $4 \mathrm{~m}$ wide, intrudes a Cretaceous biotite granite mass, 
probably within the Ryoke belt, in a seacliff at Kaura-goshi, Shirotori, Kagawa Prefecture, Shikoku (Fig. 1). It strikes $\mathrm{N} 40^{\circ} \mathrm{W}$ and dips $70^{\circ} \mathrm{E}$, conforming with the mean direction of the dike swarm $\left(\mathrm{N} 40^{\circ}\right.$ $\mathrm{W}$ and $58^{\circ} \mathrm{E}$ after Kawano and Kishida, 1940), and cuts a thin mafic dike.

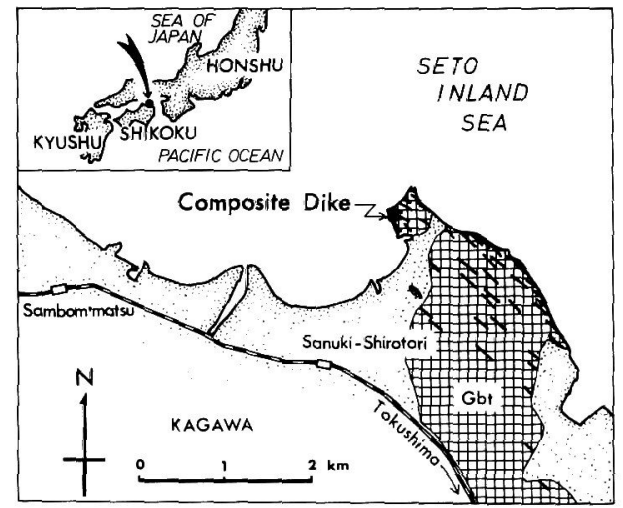

Fig. 1. Geological sketch-map showing locality of composite dike.

Dense bars: Dikes. Gbt: Cretaceous biotite granite. Stippling: Quaternary deposits.
The dike has outer dark green zones, 0.3-1.0 $\mathrm{m}$ wide, which have chilled against the country rock. There is no mutual chilling at the junction between the outer zone and inner light gray zone (Fig. 2-A). In part, the junction is straight and rather well-defined by the color difference. For the most part, it is however irregular and unclear; the color changes gradually through intermediate zones, several tens of $\mathrm{cm}$ wide. A dark gray intermediate zone, up to $0.8 \mathrm{~m}$ wide, with abundant phenocrystic plagioclase is present locally, between the outer zone and inner zone, where the junction is not sharp.

Dark brown rock inclusions from less than $5 \mathrm{~mm}$ to $20 \mathrm{~cm}$ long with short elliptical, spindle-shaped or irregularly convex-outward outline are distributed in the inner zone (Figs. 2-A and -B). They show a weak tendency to become smaller in size toward the junction as a whole. The direction of their largest dimensions seems
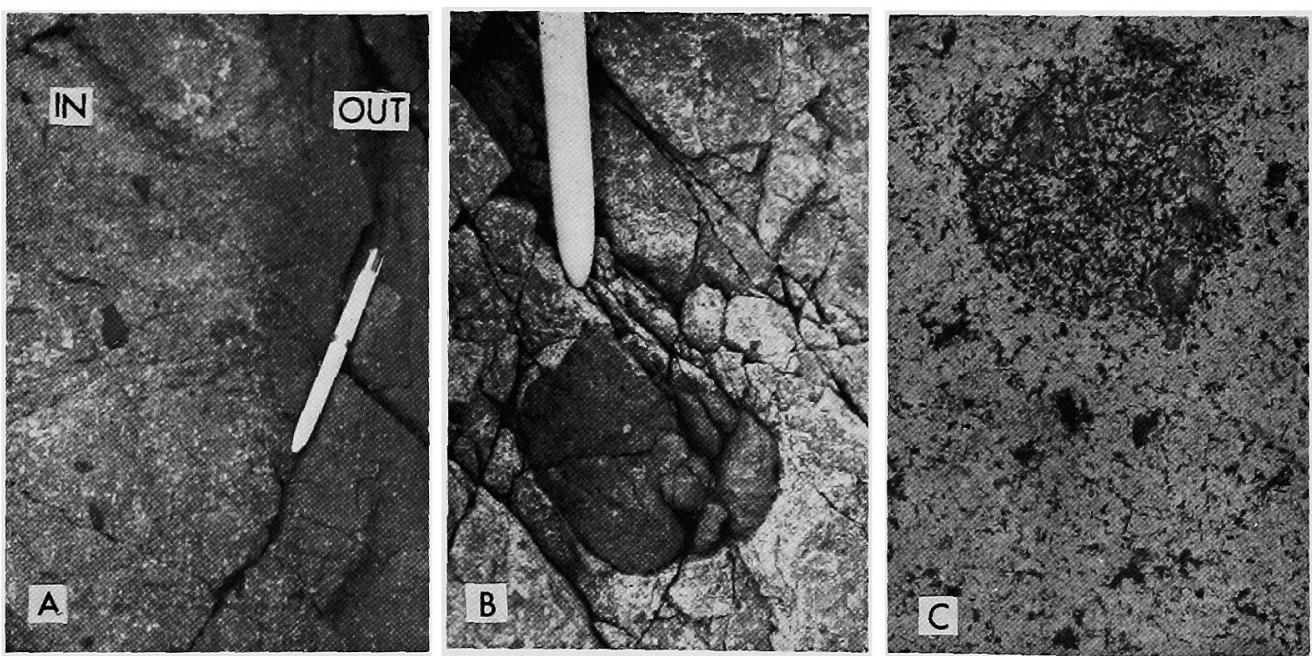

Fig. 2. A. Photograph of a part of the inner zone (IN)-outer zone (OUT) junction and rock inclusions in the composite dike. Scale given by ball-point pen.

B. Photograph of a rock inclusion in the inner zone. Scale given by a part of ballpoint pen.

C. Photomicrograph of biotite granite porphyry containing a circular melanocratic patch of about $3 \mathrm{~mm}$ diameter. Plane light. 
to be subparallel to the inner zone-outer zone junction. They make up less than $5 \%$ by volume of the zone. No indication of mutual chilling between the inclusions and the host is recognized.

\section{Petrography}

The modal composition of the dike has been determined for seven specimens on a straight line traversing its southern half where the inner zone-outer zone junction is well-defined macroscopically. The result is given in Table 1 .

Table 1. Modal analyses (vol, \%).

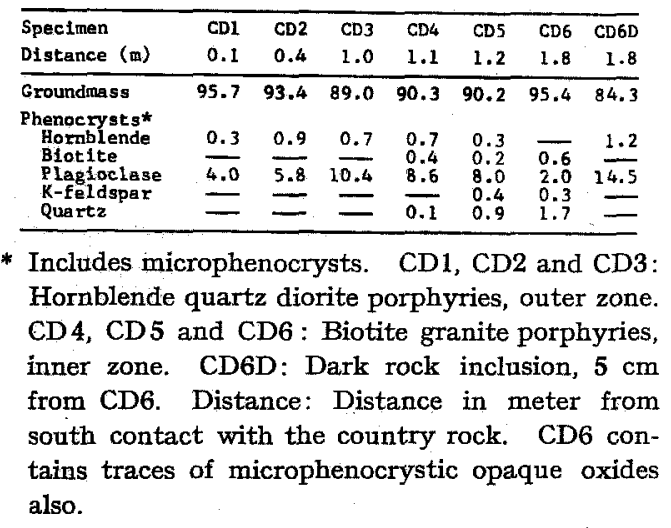

The outer dark green zone (CD1, CD2 and $\mathrm{CD} 3$ ) contains prismatic hornblende and euhedral plagioclase as phenocrysts. The hornblende phenocryst is composed of a brown core surrounded by a green mantle. Plagioclase is strongly zoned. Electron microprobe analysis of a phenocryst shows that the core is $A n_{\mathbf{7 4}}$ and the thin peripheral zone is as sodic as $\mathbf{A n}_{11}$.

Some hornblende crystals, including those in the groundmass are fringed or overgrown in part by pale greenish actinolite. The amphibole pairs with optically sharp and linear boundaries often share a common c-axis, a common composition plane of twinning and common cleavages. Actinolite usually fibrous and matted, is rarely found together with biotite and chlorite as a phenocrystic aggregate. The aggregate may be an alteration product of pyroxene, that is uralite, as judged by the outline, though no pyroxene is recognized. Actinolite in the aggregate will not be mentioned in the subsequent section of mineralogy. The origin of actinolite overgrowth is still not accounted for, but it cannot be attributed to the influence of the inner granite porphyry, since this mineral appears in simple dikes in the area as well.

The groundmass of the outer zone exhibits intersertal or interstitial texture mainly constructed by hornblende, biotite, chlorite, opaque oxides, plagioclase and quartz. Judging from the petrographic character, it is considered best to call the rock hornblende quartz diorite porphyry and not spessartite.

The biotite granite porphyry of the inner zone (CD6) contains phenocrysts of brown biotite, weakly zoned plagioclase, K-feldsapr with microperthite and corroded quartz and traces of microphenocrystic opaque oxides. The groundmass is mainly composed of quartz, plagioclase, K-feldspar, biotite, chlorite and traces of opaque oxides. Locally myrmekitic, microperthitic or micropegmatitic textures are present.

The dark brown rock inclusions (CD6D) in the inner zone contain partially sericitized plagioclase and homblende as phenocrystic phases. The hornblende is generally altered to chlorite and biotite. More often than not, it is represented solely by pseudomorphs of chlorite and biotite. The principal groundmass minerals are altered hornblende, biotite, chlorite, plagioclase, quartz and opaque oxides. Microscopically, 
rather fresh parts of the inclusions closely resemble the hornblende quartz diorite porphyry of the outer zone except for an abundance of chlorite.

Adjacent to the junction with the outer zone, the inner zone, where CD4 and CD5 came from, sporadically contains fragments of the rock inclusion of microscopic scale. The fine inclusions have circular (Fig. 2-C), elliptical, spindle-shaped or irregular outlines in thin section; they will be called "melanocratic patches" tentatively in this paper. The melanocratic patches are composed of chlorite, biotite, plagioclase and quartz mainly, and may or may not contain plagioclase and/or hornblende as phenocrysts, and vary gradually in size from less than $1 \mathrm{~mm}$ to the order of $1 \mathrm{~cm}$. Specimens of CD4 and CD5 have a phenocrystic mineral assemblage of hornblende + biotite + plagioclase + quart $\pm \mathrm{K}$-feldspar.

The groundmass very closely resembles that of the typical biotite granite porphyry represented by $\mathrm{CD} 6$, both in texture and mineral assemblage, except for the presence of sporadic patches.

\section{ChEMIGAL COMPOSITION}

The whole-rock chemical composition of the dike has been determined for the seven specimens above-mentioned. Conventional methods for silicate analysis combined with atomic absorption technique were employed. Rock fragments, homogeneous to the naked eye, were powdered selectively for analysis; but specimens of the inner zone near the junction are not free from the melanocratic patches of microscopic scale.

Table 2 shows the results of the chemical analysis; a ong with average compositions of qaurtz diorite porphyries (QDP) and biotite granite porphyries (BGP) of simple dikes in the area. The hornblende quartz diorite porphyries (CD1 and QDP) are

Table 2. Chemical analyses (wt. \%) of the composite dike with comparison.

\begin{tabular}{|c|c|c|c|c|c|c|c|c|c|}
\hline & $\begin{array}{c}1 \\
\text { CD1 }\end{array}$ & $\begin{array}{c}2 \\
\mathrm{CD} 2\end{array}$ & $\begin{array}{c}3 \\
\mathrm{CD} 3\end{array}$ & $\begin{array}{c}4 \\
\mathrm{CD} 4\end{array}$ & $\begin{array}{c}5 \\
\operatorname{CD} 5\end{array}$ & $\begin{array}{c}6 \\
\mathrm{CD} 6\end{array}$ & $\begin{array}{c}7 \\
\text { CD6D }\end{array}$ & $\begin{array}{c}8 \\
\text { QDP }\end{array}$ & $\begin{array}{c}9 \\
\text { BGP }\end{array}$ \\
\hline 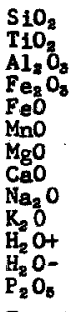 & $\begin{array}{r}56.87 \\
1.04 \\
17.70 \\
1.32 \\
6.75 \\
0.17 \\
3.60 \\
7.37 \\
2.52 \\
1.60 \\
1.21 \\
0.06 \\
0.20\end{array}$ & $\begin{array}{r}58.17 \\
0.95 \\
17.54 \\
1.33 \\
6.05 \\
0.14 \\
3.21 \\
6.93 \\
2.98 \\
1.49 \\
1.40 \\
0.07 \\
0.17\end{array}$ & $\begin{array}{r}62.64 \\
0.76 \\
16.34 \\
1.46 \\
4.80 \\
0.13 \\
2.06 \\
5.08 \\
3.44 \\
1.71 \\
1.20 \\
0.10 \\
0.16\end{array}$ & $\begin{array}{r}70.52 \\
0.26 \\
16.37 \\
0.35 \\
2.28 \\
0.07 \\
0.49 \\
1.93 \\
3.50 \\
3.31 \\
0.72 \\
0.13 \\
0.09\end{array}$ & $\begin{array}{r}73.51 \\
0.17 \\
14.61 \\
0.29 \\
1.53 \\
0.04 \\
0.30 \\
1.58 \\
3.38 \\
3.64 \\
0.61 \\
0.03 \\
0.08\end{array}$ & $\begin{array}{r}74.60 \\
0.08 \\
14.70 \\
0.26 \\
0.69 \\
0.01 \\
0.13 \\
1.01 \\
3.92 \\
4.29 \\
0.41 \\
0.112 \\
0.06\end{array}$ & $\begin{array}{r}55.97 \\
0.76 \\
16.93 \\
1.77 \\
9.64 \\
0.22 \\
2.96 \\
3.16 \\
2.70 \\
2.08 \\
3.32 \\
0.60 \\
0.17\end{array}$ & $\begin{array}{r}54.35 \\
1.21 \\
17.77 \\
1.41 \\
7.13 \\
0.18 \\
3.74 \\
8.30 \\
2.82 \\
0.78 \\
1.85 \\
0.12 \\
0.29\end{array}$ & $\begin{array}{r}75.52 \\
0.07 \\
14.00 \\
0.61 \\
0.68 \\
0.03 \\
0.05 \\
0.77 \\
3.61 \\
4.14 \\
0.49 \\
0.10 \\
0.04\end{array}$ \\
\hline Total & 100.41 & 100.43 & 99.88 & 100.02 & 92.77 & 100.28 & 100.28 & 99.95 & 100.11 \\
\hline \multicolumn{10}{|c|}{ CIPW normative ratio by welght } \\
\hline $\begin{array}{l}Q \\
O_{x} \\
\mathrm{Ab} \\
\mathrm{An}\end{array}$ & $\begin{array}{l}15.6 \\
12.7 \\
28.6 \\
43.2 \\
\end{array}$ & $\begin{array}{l}16.5 \\
11.4 \\
32.8 \\
39.2 \\
\end{array}$ & $\begin{array}{l}23.6 \\
12.2 \\
35.1 \\
29.1 \\
\end{array}$ & $\begin{array}{l}34.9 \\
21.8 \\
33.1 \\
10.1 \\
\end{array}$ & $\begin{array}{r}38.1 \\
23.2 \\
30.9 \\
7.9 \\
\end{array}$ & $\begin{array}{r}34.2 \\
26.4 \\
34.6 \\
4.9 \\
\end{array}$ & $\begin{array}{l}22.7 \\
19.1 \\
35.6 \\
22.7 \\
\end{array}$ & $\begin{array}{r}12.2 \\
6.5 \\
33.6 \\
47.2 \\
\end{array}$ & $\begin{array}{r}38.6 \\
25.7 \\
32.0 \\
3.7 \\
\end{array}$ \\
\hline $\begin{array}{l}\text { DI } \\
\text { FI } \\
\text { mg }\end{array}$ & $\begin{array}{c}42.8 \\
35.9 \\
0.44\end{array}$ & $\begin{array}{c}47.2 \\
39.2 \\
0.44\end{array}$ & $\begin{array}{c}59.7 \\
49.9 \\
0.37\end{array}$ & $\begin{array}{c}81.1 \\
77.9 \\
0.25\end{array}$ & $\begin{array}{c}86.1 \\
81.6 \\
0.21\end{array}$ & $\begin{array}{c}91.5 \\
89.0 \\
0.20\end{array}$ & $\begin{array}{c}51.6 \\
60.2 \\
0.32\end{array}$ & $\begin{array}{c}39.2 \\
30.3 \\
0.44\end{array}$ & $\begin{array}{c}92.2 \\
91.0 \\
0.06\end{array}$ \\
\hline
\end{tabular}

Analysts: O. Ujike, H. Onuki and T. Tiba.

QDP: Average composition of quartz diorite porphyry dikes of simple construction in the area (Nos. 9 and 10, Table 1 in Ujize, 1978). BGP: Average composition of biotite granite porphyry dikes of simple construction in the area (Nos. 26, 27, 28 and 29, Table 1 in Uike, 1978). DI: Differentiation index, wt. \% normative $\mathrm{Q}+\mathrm{Or}+\mathrm{Ab}$ (anhydrous basis). FI: Felsic index, $100 \times$ $\left(\mathrm{Na}_{2} \mathrm{O}+\mathrm{K}_{2} \mathrm{O}\right) /\left(\mathrm{Na}_{2} \mathrm{O}+\mathrm{K}_{2} \mathrm{O}+\mathrm{CaO}\right)$. $\mathrm{mg}: \mathrm{Mg} /\left(\mathrm{Mg}+\mathrm{Fe}^{2+}+\mathrm{Fe}^{2+}+\mathrm{Mn}\right)$. 
andesitic in composition. CD1 is slightly richer in $\mathrm{SiO}_{2}$ and $\mathrm{K}_{2} \mathrm{O}$ than simple dike rocks (QDP) of similar $\mathrm{mg}$ ratio. This is possibly due to contamination by the associated granite porphyry.

The biotite granite porphyries (CD6 and BGP) are rhyolitic in composition. Both have nearly identical differentiation index (DI) and felsic index (FI). Nevertheless, CD6 is lower in normative $\mathrm{Q} /(\mathrm{Q}+$ $\mathrm{Or}+\mathrm{Ab}$ ) ratio, and distinctly higher in $\mathrm{mg}$ $\left[=\mathrm{Mg} /\left(\mathrm{Mg}+\mathrm{Fe}^{2+}+\mathrm{Fe}^{3+}+\mathrm{Mn}\right)\right]$ ratio than BGP. The $\mathrm{MgO}$ content was determined by atomic absorption technique for the salic rocks, and so the values obtained for mg ratio are of sufficient accuracy.

The dark brown rock inclusion (CD6D) has $\mathrm{SiO}_{2}$ content comparable to $\mathrm{CD1}$. But total $\mathrm{FeO}$ and $\mathrm{CaO}$ are different from $\mathrm{CD} 1$.

In the variation diagram (Fig. 3) across the junction between the outer zone

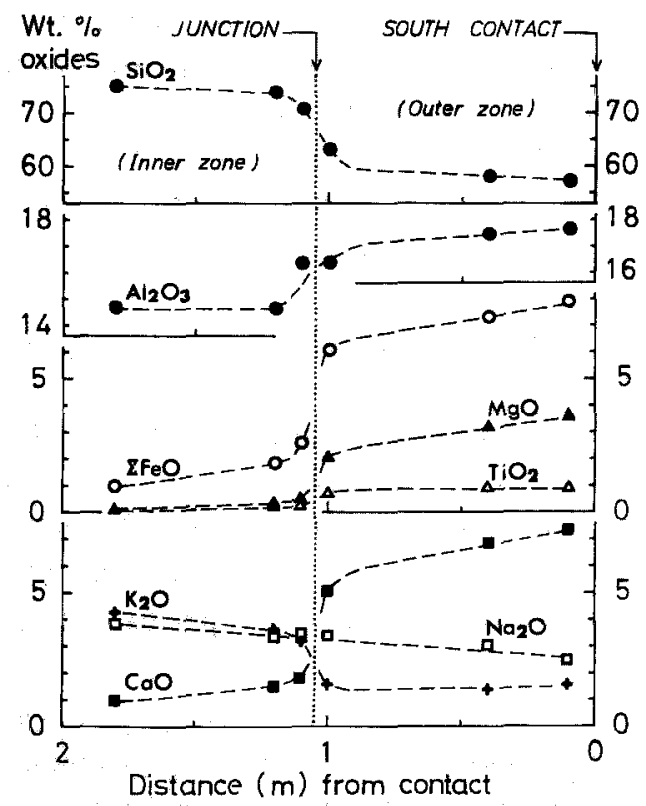

Fig. 3. Chemical variation in the composite dike with distance from contact with country rock.

Data on CD6D are omitted. Suggested trends are shown by broken lines.

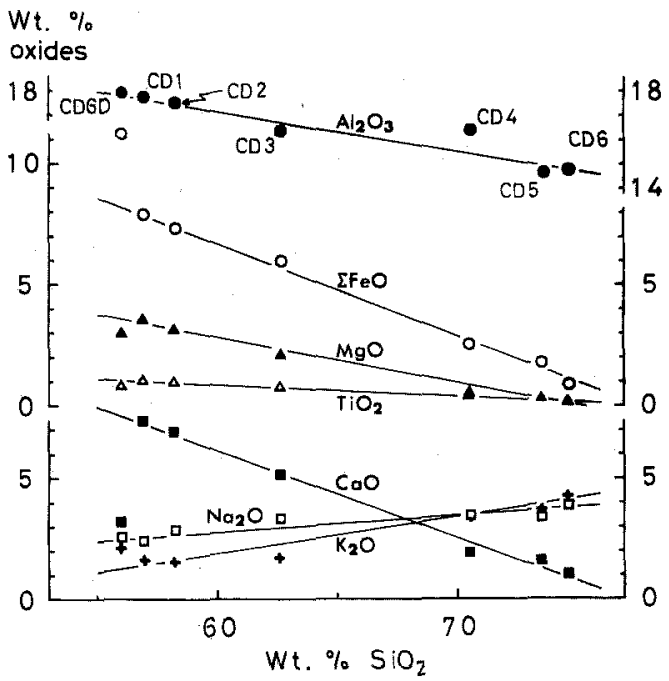

Fig. 4. Silica-variation diagram for dike ıocks.

and the inner zone, the concentration of elements varies drastically near the junction (about $105 \mathrm{~cm}$ from the south contact of the dike with the country rock). The chemical variation appears not to be very large within the main parts of each zone.

In the oxides- $\mathrm{SiO}_{2}$ variation diagram (Fig. 4), most plots, except for CD6D, are on or near straight lines; although variations of $\mathrm{Al}_{2} \mathrm{O}_{3}$ and $\mathrm{K}_{2} \mathrm{O}$ contents are rather exceptionally erratic. The chemically intermediate nature of the specimens near the junction can be explained primarily by mechanical mixing of materials represented by $\mathrm{CD} 1$ and CD6. Compositional difference between CD6 and the host in CD4 and CD5 seems microscopically to be little, if any; hence, the melanocratic patches involved must have had originally a composition similar to CD1. Taking into the account the field and microscopic observations, $\mathrm{CD} 6 \mathrm{D}$ as well as the patches must have been incorporated from the quartz diorite porphyry, while it was still plastic, and later altered to the present composition. The considerable alteration must have been 
partly due to the high water content of the magmas; which is indicated by crystallization of primary hydrous mafic silicate minerals instead of anhydrous ones throughout the dike.

It is noteworthy that the normative composition of the granite porphyries, especially that of $\mathrm{CD} 6$, is situated very close to the cotectic lines in the system $Q$ $\mathrm{Ab}-\mathrm{Or}-\mathrm{An}-\mathrm{H}_{2} \mathrm{O}$ with excess $\mathrm{H}_{2} \mathrm{O}$-rich vapor at $5 \mathrm{~kb}$ pressure determined by Winkler et al. (1975) as shown in Fig. 5. Disregarding the traces of mafic phases, CD6 contains small amounts of quartz, plagioclase and K-feldspar as phenocrysts, which is consistent with the phase relation in the cotectic melt. An absolute statement cannot be given here because phase relations and melt compositions in the system Q-Ab-Or$\mathrm{An}-\mathrm{H}_{2} \mathrm{O}$ under water-undersaturated condi-

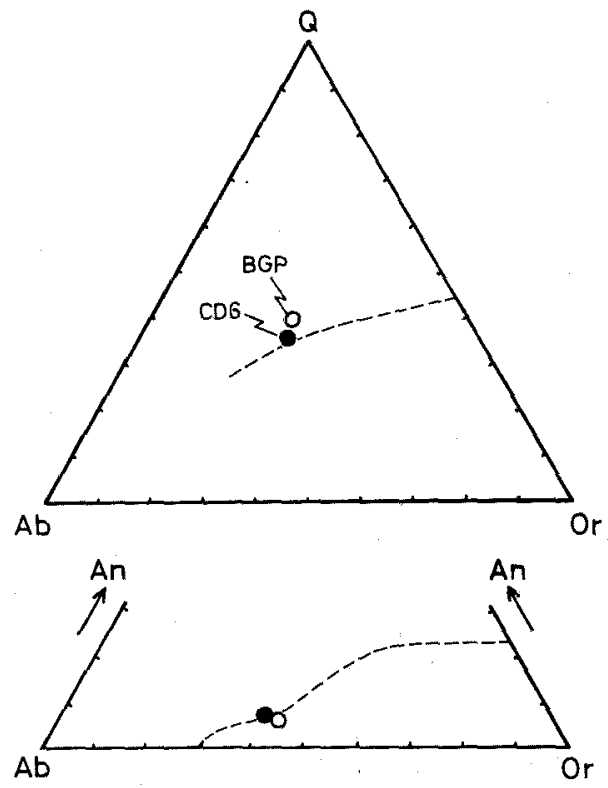

Fig. 5. Plot of CIPW normative $Q: A b:$ Or: An ratio of CD6 and BGP. Broken lines: Cotectic lines in the system Q-Ab-Or-An$\mathrm{H}_{2} \mathrm{O}$ at $P_{\mathrm{H} 2 \mathrm{O}}=5 \mathrm{~kb}$ after Winkler et al. (1975). tions are not yet known, but it is plausible that the salic magma of the composite dike was a water-saturated cotectic-like melt at depths.

\section{Mineralogy}

Salient chemical feature of amphiboles and biotites, determined by automated electron probe microanalysis (Okumura and Soya, 1976), are outlined below. Representative analyses are given in Table 3. The numbers of cations have been calculated by computer assuming all $\mathrm{Fe}$ as $\mathrm{Fe}^{2+}$. Detailed mineralogy of the dike swarm will be described in a separate paper.

Hornblende phenocryst shows zoning; $\mathrm{Al}, \mathrm{Ti}$ and $\mathrm{Mg}$ are enriched in the brown core (No. 2, Table 3), and Si, $\mathrm{Mn}$ and $\mathrm{Fe}$ in the green rim (No. 4, Table 3; see also Fig. 6). The $\mathrm{mg}$ ratio decreases monotonously towards the rim. The zoning may be explained by decrease in magmatic temperature, since hornblende formed in a silicate melt decreases in $\mathrm{Ti}$ content and increases in $\mathrm{Si}$ content with decreasing temperature at constant pressures of $\mathrm{H}_{2} \mathrm{O}$ and $\mathrm{O}_{2}(\mathrm{Helz}, 1973)$.

Some chemical characteristics of amphiboles in $\mathrm{CD} 1$ are given in Fig. 6, in which numbers of $\mathrm{Si}, \mathrm{Ti}$ and $\mathrm{Na}+\mathrm{K}$ are plotted as typical examples against $\mathrm{mg}$ ratio. The numbers of $\mathrm{Si}, \mathrm{Mn}$ and $\mathrm{Na}+\mathrm{K}$ bear a negative correlation, and those of $\mathrm{Al}$ and $\mathrm{Ti}$ bear a positive one, to the $\mathrm{mg}$ ratio in different grains of hornblende phenocryst as well as in different zones of hornblende crystals. The mode of chemical variation in the hornblende phenocryst resembles that in phenocrystic amphiboles from calcalkaline volcanic rocks of the world (Ujike, 1977), in terms of the negative Simg correlation. 
Table 3. Representative microprobe analyses of amphiboles and biotites.

\begin{tabular}{|c|c|c|c|c|c|c|c|c|c|c|c|c|c|c|}
\hline \multirow{2}{*}{$\begin{array}{l}\text { Specimen } \\
\text { Mineral }\end{array}$} & \multicolumn{9}{|c|}{$C D 1$} & \multicolumn{2}{|c|}{ CD6 } & \multirow{2}{*}{$\frac{C D 6 D}{12}$} & \multicolumn{2}{|c|}{$\mathrm{BGPa}$} \\
\hline & Hb-ph & $\begin{array}{c}2 \\
l_{k}-p h\end{array}$ & ${ }^{3}{ }^{3}-p h$ & ${ }^{4} b^{4}-p h$ & $\begin{array}{c}5 \\
\mathrm{Hb}-\mathrm{gr}\end{array}$ & $\begin{array}{c}6 \\
H b-g x\end{array}$ & Act & Act & $\begin{array}{c}9 \\
B t-g T\end{array}$ & $\begin{array}{l}10 \\
\mathrm{Bt}-\mathrm{ph}\end{array}$ & $\operatorname{Bt}_{\mathrm{Bt}-\mathrm{gr}}^{11}$ & & $\begin{array}{c}13 \\
\mathrm{BE}-\mathrm{ph}\end{array}$ & $\begin{array}{c}14 \\
B t-g r\end{array}$ \\
\hline GSJ-EP No. & 611203 & 602362 & 602370 & 602367 & 602373 & 226 & 602359 & 221 & 219 & 204 & 201 & 203 & 77,3113 & 773118 \\
\hline 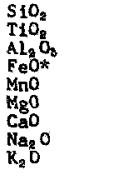 & $\begin{array}{r}42.54 \\
2.90 \\
11.72 \\
14.78 \\
0.21 \\
12.13 \\
10.77 \\
2.00 \\
0.51\end{array}$ & $\begin{array}{r}41.65 \\
2.67 \\
11.34 \\
17.24 \\
0.22 \\
10.67 \\
10.72 \\
1.84 \\
0.51\end{array}$ & $\begin{array}{r}41.99 \\
2.40 \\
11.08 \\
18.10 \\
0.25 \\
10.02 \\
10.29 \\
1.85 \\
0.47\end{array}$ & $\begin{array}{r}42.78 \\
1.77 \\
10.62 \\
20.21 \\
0.32 \\
8.34 \\
10.37 \\
1.75 \\
0.53\end{array}$ & $\begin{array}{r}46.26 \\
1.88 \\
8.15 \\
19.00 \\
0.58 \\
9.75 \\
10.00 \\
1.25 \\
0.36\end{array}$ & $\begin{array}{r}44.38 \\
1.67 \\
9.92 \\
20.88 \\
0.46 \\
8.86 \\
9.95 \\
1.38 \\
0.44\end{array}$ & $\begin{array}{r}52.95 \\
0.12 \\
2.20 \\
16.39 \\
0.55 \\
12.61 \\
12.34 \\
0.22 \\
0.06\end{array}$ & $\begin{array}{r}48.97 \\
0.31 \\
5.42 \\
18.33 \\
0.54 \\
10.73 \\
11.97 \\
0.62 \\
0.24\end{array}$ & $\begin{array}{r}36.45 \\
3.75 \\
14.53 \\
21.97 \\
0.24 \\
9.16 \\
0.06 \\
0.07 \\
9.09\end{array}$ & $\begin{array}{r}34.59 \\
3.94 \\
15.09 \\
27.81 \\
0.44 \\
4.66 \\
0.03 \\
0.06 \\
8.98\end{array}$ & $\begin{array}{r}33.76 \\
2.98 \\
15.92 \\
28.64 \\
0.45 \\
3.82 \\
0.02 \\
0.05 \\
9.03\end{array}$ & $\begin{array}{r}36.25 \\
2.56 \\
14.05 \\
26.23 \\
0.47 \\
6.87 \\
0.04 \\
0.06 \\
8.85\end{array}$ & $\begin{array}{r}34.05 \\
4.80 \\
15.08 \\
29.54 \\
0.64 \\
2.36 \\
0.01 \\
0.14 \\
8.50\end{array}$ & $\begin{array}{r}32.44 \\
0.58 \\
18.90 \\
32.47 \\
0.69 \\
0.95 \\
0.07 \\
0.07 \\
8.42\end{array}$ \\
\hline Total & 97.56 & 96.86 & 96.45 & 96.69 & 97.23 & 97.94 & 97.44 & 97.13 & 95.32 & 95.60 & 94. & 95.38 & 95.12 & 94.59 \\
\hline \multicolumn{15}{|c|}{ Numbers of cations per 23 oxygens (amphiboles) and 22 oxygens (biotites) } \\
\hline $\begin{array}{l}z\left\{\begin{array}{l}\mathrm{SI} \\
\mathrm{Al} \\
\mathrm{IV}\end{array}\right. \\
y\left\{\begin{array}{l}\mathrm{Al} \\
\mathrm{TI} \\
\mathrm{Fe}^{2} \\
\mathrm{Mn} \\
\mathrm{Mg}\end{array}\right. \\
\times\left\{\begin{array}{l}\mathrm{Ga} \\
\mathrm{Ga} \\
\mathrm{Ma} \\
\mathrm{K}\end{array}\right.\end{array}$ & $\begin{array}{l}6.329 \\
1.671 \\
0.385 \\
0.325 \\
1.839 \\
0.026 \\
2.690 \\
1.718 \\
0.578 \\
0.097\end{array}$ & $\begin{array}{l}6.324 \\
1.676 \\
0.355 \\
0.305 \\
2.189 \\
0.029 \\
2.415 \\
1.744 \\
0.543 \\
0.098\end{array}$ & $\begin{array}{l}6.415 \\
1.585 \\
0.410 \\
0.276 \\
2.313 \\
0.032 \\
2.280 \\
1.684 \\
0.547 \\
0.093\end{array}$ & $\begin{array}{l}6.571 \\
1.429 \\
0.494 \\
0.205 \\
2.596 \\
0.041 \\
1.910 \\
1.706 \\
0.521 \\
0.104\end{array}$ & $\begin{array}{l}6.962 \\
1.038 \\
0.408 \\
0.213 \\
2.391 \\
0.074 \\
2.188 \\
1.613 \\
0.366 \\
0.069\end{array}$ & $\begin{array}{l}6.710 \\
1.290 \\
0.477 \\
0.190 \\
2.640 \\
0.058 \\
1.996 \\
1.611 \\
0.406 \\
0.085\end{array}$ & $\begin{array}{l}7.787 \\
0.213 \\
0.168 \\
0.013 \\
2.016 \\
0.068 \\
2.764 \\
1.945 \\
0.063 \\
0.011\end{array}$ & $\begin{array}{l}7.345 \\
0.655 \\
0.304 \\
0.035 \\
2.299 \\
0.068 \\
2.399 \\
1.924 \\
0.179 \\
0.047\end{array}$ & $\begin{array}{l}5.632 \\
2.368 \\
0.278 \\
0.436 \\
2.839 \\
0.032 \\
2.109 \\
0.010 \\
0.020 \\
1.793\end{array}$ & $\begin{array}{l}5.507 \\
2.493 \\
0.339 \\
0.472 \\
3.703 \\
0.060 \\
1.105 \\
0.005 \\
0.018 \\
1.824\end{array}$ & $\begin{array}{l}5.460 \\
2.540 \\
0.496 \\
0.363 \\
3.874 \\
0.061 \\
0.922 \\
0.004 \\
0.016 \\
1.864\end{array}$ & $\begin{array}{l}5.717 \\
2.283 \\
0.329 \\
0.303 \\
3.459 \\
0.063 \\
1.615 \\
0.007 \\
0.019\end{array}$ & & $\begin{array}{l}5.333 \\
2.667 \\
0.995 \\
0.097 \\
4.464 \\
0.096\end{array}$ \\
\hline $\begin{array}{l}z \\
y \\
x \\
\end{array}$ & $\begin{array}{l}8.000 \\
5: 265 \\
2.393 \\
\end{array}$ & $\begin{array}{l}8.000 \\
5.293 \\
2.385 \\
\end{array}$ & $\begin{array}{l}8.000 \\
5.311 \\
2.324 \\
\end{array}$ & $\begin{array}{l}8.000 \\
5.246 \\
2.331 \\
\end{array}$ & $\begin{array}{l}8.000 \\
5.274 \\
2.048 \\
\end{array}$ & $\begin{array}{l}8.000 \\
5.361 \\
2.102 \\
\end{array}$ & $\begin{array}{l}8.000 \\
5.029 \\
2.019 \\
\end{array}$ & $\begin{array}{l}8.000 \\
5.105 \\
2.150 \\
\end{array}$ & $\begin{array}{l}8.0 \\
5.6 \\
1.8 \\
\end{array}$ & $\begin{array}{l}8.000 \\
5.679 \\
1.847 \\
\end{array}$ & $\begin{array}{l}00 \\
16 \\
84 \\
\end{array}$ & $\begin{array}{l}8.000 \\
5.769 \\
1.806 \\
\end{array}$ & & \\
\hline ng & 0.591 & 0.521 & 0.493 & 0.420 & 0.470 & 0.425 & 0.570 & 0.503 & 0.423 & 0.227 & 0.190 & 0.314 & 0.122 & 0.049 \\
\hline
\end{tabular}

* Total iron as FeO. Hb: Hornblende. Act: Actinolite. Bt: Biotite. ph: Phenocryst. gr: Groundmass. BGPa: A salic dike of simple construction (No. 26, Table 1 in Ujike, 1978) whose analysis was used for getting the average composition (BGP). GSJ-EP No.: Analysis number by the automated electron probe microanalyzer at the Geological Survey of Japan. Chemical zoning in a hornblende phenocryst is shown by Nos. 2 (core), 3 and 4 (rim).

Nos. of

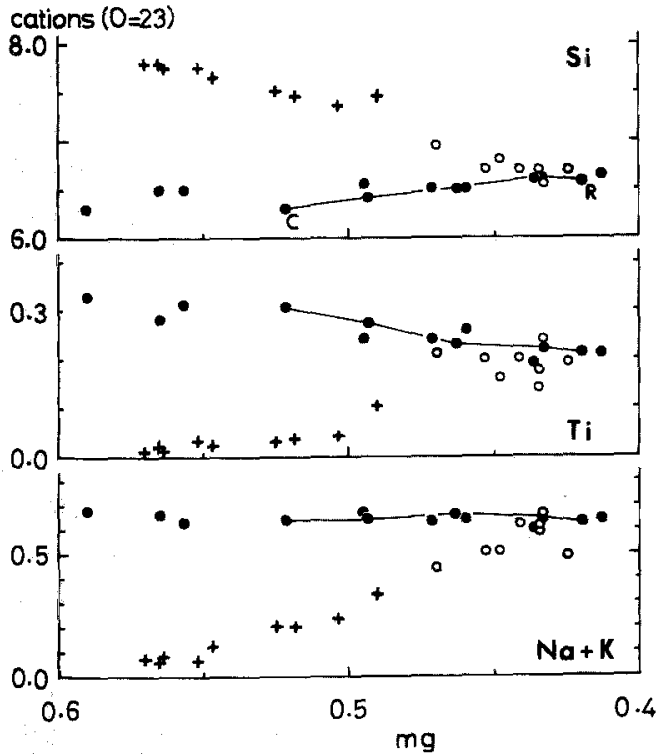

Fig. 6. Plot of $\mathrm{Si}, \mathrm{Ti}$ and $\mathrm{Na}+\mathrm{K}$ vs. $\mathrm{mg}$ for $\mathrm{am}-$ phiboles in CD1. Circles: Hornblendes of phenocryst (solid) and groundmass (open). Crosses: Actinolites. Tie-lines from C (core) to $R$ (rim): Zoning of a phenocryst.
Groundmass hornblendes (Nos. 5 and 6, Table 3) tend to contain more of $\mathrm{Si}$ and $\mathrm{Mn}$ and less of $\mathrm{Ti}, \mathrm{Al}$ and $\mathrm{Na}+\mathrm{K}$ than hornblende phenocrysts of the similar $\mathrm{mg}$ ratio.

Actinolite (Nos. 7 and 8, Table 3) overgrown on hornblende is richer in $\mathrm{Si}$, $\mathrm{Mn}$ and $\mathrm{Ca}$; and poorer in $\mathrm{Al}, \mathrm{Ti}$ and $\mathrm{Na}+\mathrm{K}$ than the hornblende phenocryst. Plots for $\mathrm{Si}$ and $\mathrm{Na}+\mathrm{K}$ in the actinolite and the groundmass hornblende seems to lie on smooth curves in Fig. 6. Like amphiboles from some Japanese granites (Kanisawa, 1976), both the actinolite and the groundmass hornblende show a positive Si-mg correlation.

Biotite occurs as phenocryst (No. 10, Table 3 ) in the granite porphyry and as groundmass (Nos. 9, 11 and 12, Table 3) throughout the composite dike. The phenocryst has $\mathrm{mg}$ ratios and $\mathrm{Ti}$ contents higher than the groundmass biotite not only in $\mathrm{CD} 6$ but also in another dike of 


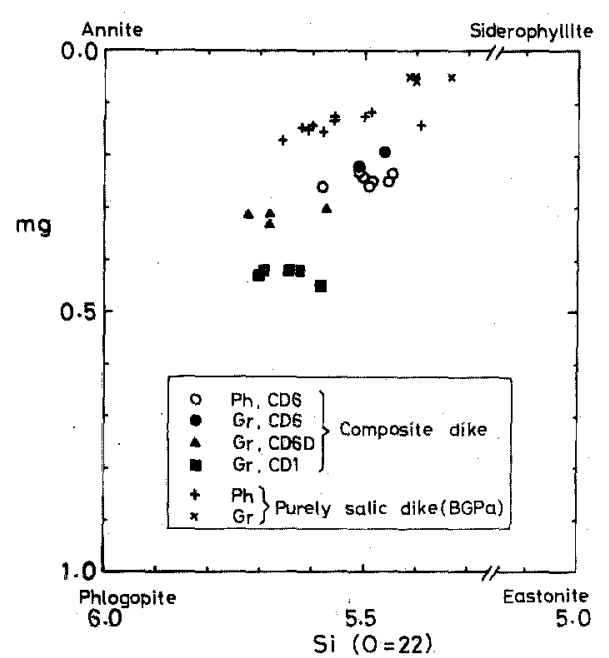

Fig. 7. Plot of mg vs. Si for biotites in the composite dike and a purely salic dike. Ph: Phenocryst. Gr: Groundmass. BGPa: See explanation of Table 3.

purely salic composition in the area (BGPa, Table 3). The mg-Si relation is summarized in Fig. 7. The biotite in the granite porphyry of the composite dike (CD6) are distinctly higher in $\mathrm{mg}$ ratio than those in the purely salic dike (BGPa). The mg values of the groundmass biotite are in ranges of $0.42-0.45, \quad 0.30-0.33,0.19-0.22$ and $0.05-0.06$. In the rocks, $\mathrm{CD} 1$ has $\mathrm{mg}=$ 0.44; $\mathrm{CD} 6 \mathrm{D}$ has $\mathrm{mg}=0.32$; $\mathrm{CD} 6$ has $\mathrm{mg}=$ 0.20 ; and $\mathrm{BGP}(\sim \mathrm{BGPa})$ has $\mathrm{mg}=0.06$ (Table 2). This indicates that the $\mathrm{mg}$ ratio of groundmass biotite is directly related to that of the host rock.

\section{Discússion}

A model wherein contemporaneous salic and intermediate magmas are generated by fractional fusion of a common parental material (Yoder, 1973) is not applicable to the origin of the composite dike described. In chemical composition, except a slight difference in concentration of such elements as $\mathrm{SiO}_{2}$ and $\mathrm{K}_{2} \mathrm{O}, \mathrm{CD} 1$ is similar to the in- termediate members (QDP) of a tholeiitic series of numerous dike rocks of simple construction in the area; and the "Daly gap" cannot be recognized in the dike swarm (Ujike, 1978). It is not reasonable to consider that the magma of CD1 was a product of fractional fusion, since this process cannot yield a continuous magma series.

The salic phase of the composite dike (CD6) is different in mg ratio from purely salic dike rocks or salic end-members (BGP) of the tholeiitic series. The high-mg character cannot be explained by derivation of CD6 by contamination with the associated magma of CD1 during and after the emplacement from a magma, now represented by BGP compositionally, common to all dikes of the biotite granite porphyry intruded in the area. The evidence is that the biotite phenocryst of CD6 is distinctly higher in mg ratio than that of $\mathrm{BGP}(\sim \mathrm{BGPa})$ and in harmony with the $\mathrm{mg}$ ratio of the groundmass biotites (Fig. 7) and the host rocks. The CD6 magma must have already been high in $\mathrm{mg}$ ratio at the phenocrystic stage of magmatic crystallization. It is suggested that CD6 magma was contaminated to the present composition by CD1 magma at the early stage of magmatic activity.

On the other hand, the field observation that the most dikes of the swarm have intruded by intervals is an evidence against, but not excluding entirely a possibility of, the contemporaneity of two voluminous magmas of contrasting composition in the area. The CD6 magma might be a melt due to small-scale fusion of a certain crustal material with high-mg ratio and CD1 magma might be the heat source.

The data in hand is insufficient to specify the magma genesis of the composite dike. It can be concluded, however, at 
present that the Kaura-goshi composite dike was formed by no means incidentally by successive injections of two magmas with no genetic relationship; the intermediate magma (CD1) seems to have had affected essentially to the derivation of salic magma (CD6) of the present composition in any case.

\section{AGKNOWLEDGEMENTS}

The writer wishes to express his deep gratitude to H. Onuki (Tohoku Univ.) and T. Tiba (Natn. Sci. Mus., Tokyo) for taking part in chemical analysis with atomic absorption spectrometry; K. Okumura and T. Soya (Geol. Surv. Japan) for their assistance and for making microprobe facilities available; and G.R. Balce (Bureau of Mines, Philippines) for reading and correcting an early draft of the manuscript.

\section{REFERENGES}

Helz, R.T. (1973), Phase relations of basalts in their melting range at $P_{\mathrm{H}_{2} \mathrm{O}}=5 \mathrm{~kb}$ as a function of oxygen fugacity, Part I. Mafic phases. $J$. Petrology, 14, 249-302.

Kanisawa, S. (1976), Chemical compositions of hornblendes and biotites in granitic rocks. J. Japan. Assoc. Min. Pet. Econ. Geol., Spec. Pap. 1, 243-249 (in Japanese).

Kawano, $Y$ and Kishida, K. (1940), On spessartites and granophyres of a dike swarm in the vicinity of Shirotori-honmachi, Kagawa Prefecture. J. Japan. Assoc. Min. Pet. Econ. Geol., 23, 165-178 (in Japanese).

Ohara, S. (1976), On a dike swarm in the vicinity of Shirotori-cho, Kagawa Prefecture. Memoir in honour of Professor G. Kojima's 60th birthday, 245-250 (in Japanese).

Okumura, K. and Soya, T. (1976), Quantitative analysis of silicate by automated electron probe microanalyzer. $J$. Mineral. Soc. Japan, 12. Spec. Issure, 116-124 (in Japanese).

Popov, V.S. (1976), Symmetric composite dikespossible mechanism of formation and petrologic consequences. Internat. Geol. Rev., 18, 867874.

Sato, M. (1936), The geological sheet map "Takamatsu", scale 1:75,000, and its explanatory text. 56 pp. Tokyo: Imp. Geol. Surv. Japan (in Japanese with English abstract).

Ujike, O. (1977), Chemical compositions of amphibole phenocrysts in calc-alkaline volcanic rocks: A compilation of 95 analyses. $J$. Japan. Assoc. Min. Pet. Econ. Geol., 72, 8391 (in Japanese with English abstract).

(1978), The diversity of a dike swarm in the vicinity of Shirotri-cho, Kagawa Prefecture. Bull. Geol. Surv. Japan, 29, 85-97 (in Japanese with English abstract).

Walker, G.P.L. and Skelhorn, R.R. (1966), Some associations of acid and basic igenous rocks. Earth-Sci. Rev., 2, 93-109.

Winkler, H.G.F., Bose, M. and Marcopoulos, T. (1975), Low temperature granitic melts. $N$. Jb. Mineral. Mh., 1975, 245-268.

Yoder, H.S., Jr. (1973), Contemporaneous basaltic and rhyolitic magmas. Am. Mineral., 58, 153171.

\section{香川県白鳥町の黒雲母花崗岩ポーフィリー・角閃石 石英閃緑岩ポーフィリー複合岩脈}

標記複合岩脈の内部をなす珪長質部 $\left(\mathrm{SiO}_{2}=75 \%\right)$ 亿は，両側の石英閃緑岩ポーフィリー $\left(\mathrm{SiO}_{2}=57 \%\right)$ と同

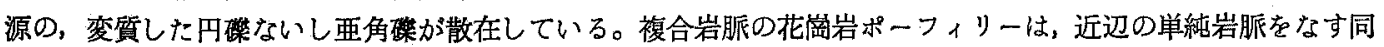
質岩に比べて，全岩・斑晶および石基の黒雲母のすべてが，非常に高い $\mathrm{mg}\left[=\mathrm{Mg} /\left(\mathrm{Mg}+\mathrm{Fe}^{2+}+\mathrm{Fe}^{3+}+\mathrm{Mn}\right)\right]$ 比を示す。複合岩脈として貫入した珪長質マグマは，マグマ溜り形成時またはそれ以前に，随伴する石英閉緑岩 質マグマによって污染されたと考えられるが，mg 比の高い物質の局部的な溶融によって生じた可能性もある。

(地名) Kaura-goshi 鹿浦越 